\title{
Evaluation of functional and nutritional potential of a protein concentrate from Pleurotus ostreatus mushroom
}

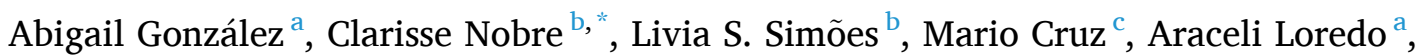 \\ Rosa M. Rodríguez-Jasso ${ }^{a}$, Juan Contreras ${ }^{a}$, José Texeira ${ }^{\mathrm{b}}$, Ruth Belmares ${ }^{\mathrm{a}, *}$ \\ ${ }^{a}$ Food Research Department, Faculty of Chemistry, Autonomous University of Coahuila, Blvd. V. Carranza and Ing, José Cárdenas s/n Col, República, 25280 Saltillo, \\ Coahuila, Mexico \\ ${ }^{\mathrm{b}}$ CEB - Centre of Biological Engineering, University of Minho, Campus de Gualtar, 4710-057 Braga, Portugal \\ ${ }^{\mathrm{c}}$ Food Science and Technology Department, Antonio Narro Autonomous Agrarian University, Calzada Antonio Narro, No. 1923 Col, Buena Vista, 25315 Saltillo, \\ Coahuila, Mexico
}

\section{A R T I C L E I N F O}

\section{Keywords:}

Protein concentrate

Pleurotus ostreatus

Edible mushroom

In vitro digestion

Hydrolysis degree

Antioxidant activity

\begin{abstract}
A B S T R A C T
Edible mushrooms used as a protein-rich food may be an attractive alternative to conventional protein sources, while promoting its valorization. This work aimed to obtain a protein concentrate from a Pleurotus ostreatus mushroom flour, its characterization, and nutritional and functional properties evaluation. Methodologies applied for extraction and precipitation of protein were optimized - $\mathrm{pH} 4$ and 12, respectively; and flour-solvent ratio of $1: 20 \mathrm{w} / \mathrm{v}$. The protein density was increased by $78 \%$. P. ostreatus flour and concentrate were characterized by proximal composition. The content of total phenolic compounds in the protein concentrate decreased, leading to a positive effect on protein digestibility, while the DPPH radical scavenging activity was not significantly affected. Peptides with molecular weights from 12 to $35 \mathrm{kDa}$, with possible bioactivity, were identified by electrophoresis. Protein digestibility assessed by in vitro gastrointestinal digestion showed a 4.2-fold higher hydrolysis degree in the protein concentrate than the flour.
\end{abstract}

\section{Introduction}

Protein is an essential macronutrient to human body growth and maintenance due to its important physiological functions, such as vital performance of hormones and enzymes action (Bhutta, Sadiq, \& Aga, 2013). Proteins of animal origin have a high nutritional quality. However, its associated production cost is extremely high when compared to the production of vegetable proteins. For instance, the production of 1 $\mathrm{kg}$ of meat requires between 5 and 40 times more water than the production of $1 \mathrm{~kg}$ of cereal, which increases the meat production cost up to 10 times. Meat production also leads to high greenhouse gas emission, resulting in a relevant environmental impact (Kumar et al., 2017). In addition, some foods of animal origin (e.g., red and processed meats) have been associated with human health risks, namely cardiovascular diseases and colon cancer (Windey, Preter, \& Verbeke, 2012; Wolfe, Baum, Starck, \& Moughan, 2018). One possible way to overcome these issues is to promote the consumption of other protein sources (e.g., protein from vegetal and fungal sources).

The interest in proteins from plant sources as an alternative to animal proteins has been growing in the last decades. Mainly due to its reduced production cost, abundant supply, and content of bioactive and phytochemical substances (Sá, Moreno, \& Carciofi, 2020). However, the use of plant protein is still limited, as it lacks one or more essential amino acids to classify it as a complete protein (Kurpad, 2013). For example, cereals contain low-values of lysine, and legumes are deficient in sulfur amino acids (e.g., methionine and cysteine) (Sá et al., 2020).

Recently, proteins of fungal origin have gained the attention from food industry players and scientific community, due to its high nutritional values associated to the rich level of essential amino acids when compared to vegetables (Bach et al., 2017). Generally, the cultivation of mushrooms is faster and cheaper as compared to vegetables, since they can be easily cultivated using agro-industrial residues (Lavelli, Proserpio, Gallotti, Laureati, \& Pagliarini, 2018). Moreover, mushroom proteins have high thermal and $\mathrm{pH}$ stability (Erjavec, Kos, Ravnikar, Dreo, \& Sabotič, 2012). The use of edible mushrooms for the development of protein rich food products could provide an attractive alternative to an animal protein source while promoting its valorization.

It has been reported that the protein digestibility of mushrooms

\footnotetext{
* Corresponding authors.

E-mail addresses: clarissenobre@gmail.com (C. Nobre), ruthbelmares@uadec.edu.mx (R. Belmares).
} 
ranges from 60 to $70 \%$ (Lavelli et al., 2018). However, the digestibility of proteins can be improved by removing food components that hamper its hydrolysis in the gastrointestinal tract. For instance, fiber content decreases protein density; reducing sugars are subject to Maillard reaction and decrease the assimilable lysine, methionine, and tryptophan; residual lipids can be oxidized leading to rancidity, or when associated with proteins can cause thickening problems during food processing and storage (Vioque, Sánchez-Vioque, Pedroche, Yust, \& Millán, 2001). In addition, it has been reported that edible mushrooms possess bioactive peptides with beneficial effects for human health (e.g., antimicrobial, hypocholesterolemic), which are inactive within the protein, but can be released during enzymatic proteolysis (e.g., gastrointestinal digestion, in vitro hydrolysis with proteases) or by food processing (e.g., cooking, fermentation, ripening), providing the functional properties associated to such peptides (Xu, Yan, Chen, \& Zhang, 2011). Moreover, phenolic compounds in mushrooms have been related with antioxidant activity, inhibition of lipid peroxidation, scavenge reactive oxygen species, and chelating activity on ferrous ions (Jayakumar, Thomas, Sheu, \& Geraldine, 2011).

Despite all these studies on mushrooms, there is a lack of information regarding the processing of its protein concentrate and on elucidation of how this process affects the protein digestibility and its antioxidant activity. In this regard, this study aims to evaluate the edible mushroom $P$. ostreatus flour as a raw material for development of a protein concentrate.

\section{Materials and methods}

\subsection{Reagents}

The following chemicals were purchased from Sigma-Aldrich (St. Louis, MO, USA): sodium carbonate ( $\geq 99 \%$ ), copper(II) sulfate pentahydrate $(\geq 98 \%)$, potassium sodium tartrate tetrahydrate $(\geq 99 \%)$, sodium hydroxide $(\geq 97 \%)$, Folin-Ciocalteu's phenol reagent, Bovine Serum Albumin (BSA), sodium dodecyl sulfate (SDS), $\beta$-mercaptoethanol, bromophenol blue, Coomassie Brilliant Blue (R-250), tetramethylethylenediamine (TEMED), gallic acid (3,4,5 trihydroxybenzoic acid), 2,2 diphenyl-1picrylhydrazyl (DPPH), 2,2'-Azino-bis(3-ethylbenzothiazoline-6-sulfonic acid) (ABTS), 6-hydroxy-2,5,7,8-tetramethylchroman-2-carboxylic acid (Trolox), pepsin from porcine gastric mucosa, $\alpha$ - amylase and pancreatin from porcine pancreas, bile extract porcine and pefabloc ${ }^{\circledR}$ SC. Acrylamide/Bis solution (29:1) was purchased from Bio-Rad (California, USA), whereas calcium chloride was obtained from Panreac (Barcelona, Spain). Hydrochloric acid, $n$-hexane $(\geq 95 \%)$, methanol, glacial acetic acid, and 2,4,6 trinitrobenzene sulfonic acid (TNBSA) were purchased from Thermo Fisher Scientific (Bremen, Germany) whereas serine was obtained from Acros Organics (Belgium).

\subsection{Raw material preparation}

P. ostreatus mushrooms were grown at the Antonio Narro Autonomous Agrarian University. The mushrooms were cultivated in dark conditions for 40 days, at temperature ranging between 25 and $28{ }^{\circ} \mathrm{C}$ with $60 \%$ moisture, using sorghum forage as substrate. P. ostreatus flour was obtained by drying the fruiting bodies in an electric oven, at a temperature of $60{ }^{\circ} \mathrm{C}$ for $72 \mathrm{~h}$ (Tolera \& Abera, 2017) followed by grinding in a Retsch ${ }^{\circledR}$ SM 100 grinder and sifting through a $355 \mu \mathrm{m}$ sieve.

\subsection{Optimization of process conditions to obtain a protein concentrate}

Initially, the P. ostreatus flour was defatted according to Cruz-Solorio, Garín-Aguilar, Leal-Lara, Ramírez Sotelo \& Valencia-del Toro (2014) methodology. Mushroom flour was dispersed in $n$-hexane solution at a ratio of 1:5 $(\mathrm{w} / \mathrm{v})$, continuously stirred with magnetic agitation at a rotation speed of $80 \mathrm{rpm}$ during $8 \mathrm{~h}$ at $4{ }^{\circ} \mathrm{C}$. Subsequently, the hexane was decanted to remove fat, and the powder was allowed to dry completely. The methodology used to obtain the protein concentrate was studied in terms of the effect of $\mathrm{pH}$ value and flour-solvent ratio upon protein solubilization.

\subsubsection{Protein solubility}

The protein solubility was evaluated according to the method described by Cruz-Solorio et al. (2014) with some modifications. Briefly, $1 \%(\mathrm{w} / \mathrm{v})$ P. ostreatus flour was dispersed in distilled water, and the $\mathrm{pH}$ value of the solution was adjusted by ranging between 2 and 12 using 1 mol L ${ }^{-1} \mathrm{HCl}$ and/or $1 \mathrm{~mol} \mathrm{~L}^{-1} \mathrm{NaOH}$, as necessary. Subsequently, the resulting solutions were agitated in a vortex and centrifuged at $12400 \times$ $g$ for $30 \mathrm{~min}$ Then, the soluble protein was evaluated in the supernatant following Lowry, Rosebrough, Farr \& Randall (1951) methodology. For this purpose, the sample $(100 \mu \mathrm{L})$ was mixed with $25 \mu \mathrm{L}$ of a solution containing $2 \% \mathrm{Na}_{2} \mathrm{CO}_{3}, 1 \% \mathrm{CuSO}_{4} \cdot 5 \mathrm{H}_{2} \mathrm{O}$ and $2 \%$ sodium-potassium tartrate (at 1:1:8 ratio), and maintained in dark conditions, at room temperature for $10 \mathrm{~min}$. Then, $10 \mu \mathrm{L}$ of the diluted Folin-Ciocalteau reagent (1:2) was added to the sample, which remained for $30 \mathrm{~min}$ in the same conditions as previously described. The protein solubility was quantified by measurement of the absorbance at wavelength $630 \mathrm{~nm}$ in Synergy ${ }^{\mathrm{TM}}$ HT Multi-mode Microplate Reader (Biotek Instruments, Winooski, VT, USA). Standard solutions of BSA were used to establish an appropriate calibration curve $\left(\mathrm{y}=0.0008 \mathrm{x}+0.0129 ; \mathrm{R}^{2}=0.98\right.$; where $y$ and $x$ were the absorbance and concentration of BSA, respectively).

\subsubsection{Mushroom-solvent ratio}

Mushroom flour was dispersed in distilled water at several ratios $(1: 5,1: 10$, and $1: 20 \mathrm{w} / \mathrm{v})$. The $\mathrm{pH}$ of the solution was adjusted to the value whereby the maximum protein solubility was achieved in the previous assay ( $\mathrm{pH} \mathrm{12}$ ) using $2 \mathrm{~mol} \mathrm{~L}^{-1} \mathrm{NaOH}$. Afterward, the mushroom flour solution was centrifuged at $12400 \times g$ for $20 \mathrm{~min}$ at $4{ }^{\circ} \mathrm{C}$. The supernatant was collected, and the solution was adjusted to the isoelectric $\mathrm{pH}$ value ( $\mathrm{pH} 4$, previously assessed) with $2 \mathrm{~mol} \mathrm{~L}^{-1} \mathrm{HCl}$. Then, the sample was centrifuged again using the same conditions established previously, and the precipitate was collected. An aliquot $(1 \mathrm{~mL})$ of each supernatant was used for soluble protein content determination, as described in Section 2.3.1. Protein concentrate samples were dehydrated by freeze-drying, in order to obtain a lyophilized powder. Protein yield was estimated by the following equation:

Yield $(\%)=\left(\frac{E P}{T P}\right) \times 100$

where $E P$ is the amount of extracted protein $(\mathrm{g})$ and $T P$ is the amount of total protein $(\mathrm{g})$ in the mushroom flour.

\subsection{Proximate analysis}

The amount of moisture, ash, lipids, protein, crude fiber, and carbohydrates of $P$. ostreatus flour and the protein concentrate were determined by AOAC methods (A.O.A.C, 1995).

\subsection{Electrophoresis}

The electrophoretic profile of the protein concentrate was determined following the protocol used by Kimatu et al. (2017) with some modifications. Sodium dodecyl sulfate-polyacrylamide gel electrophoresis (SDS-PAGE) was carried out using a Mini-PROTEAN Tetra Vertical Electrophoresis Cell (Bio-Rad $\AA$ ) at $400 \mathrm{~mA}$ and $115 \mathrm{~V}$. The resolving and stacking gel contained $30 \%$ acrylamide/bis solution (29:1) at concentrations of $12 \%$ and $30 \%$, respectively. Samples were prepared at $20 \mathrm{mg}$ $\mathrm{mL}^{-1}$ in deionized sterile water and filtered through $0.45 \mu \mathrm{m}$ nylon membrane filter (Corning ${ }^{\circledR}$ ). The loading buffer containing $2 \% \mathrm{w} / \mathrm{v}$ SDS, $5 \% \mathrm{v} / \mathrm{v} \beta$-mercaptoethanol, $1 \% \mathrm{v} / \mathrm{v}$ glycerol and $0.001 \% \mathrm{w} / \mathrm{v}$ 
bromophenol blue, was mixed with protein concentrate samples (4:1 ratio). The resulting solution was heated at $95{ }^{\circ} \mathrm{C}$ during 5 min through a temperature-controlled water bath to promote protein denaturation. The gel was stained with a Coomassie Blue (R-250) solution, containing $40 \%$ and $10 \%$ of methanol and glacial acetic acid, respectively. Then, the gel was destained with acetic acid and methanol solution, both at concentration of $10 \%$. Standard marker Bio-Basic ${ }^{\circledR}$ prestained protein ladder (molecular weight ranging from 10 to $250 \mathrm{kDa}$ ) was used to identify the sample by their molecular weight.

\subsection{Total phenolic content and antioxidant capabilities}

\subsubsection{Determination of total phenols}

Total phenolic content of mushroom flour and protein concentrate was determined by the Folin-Ciocalteu assay according to the method used by Goiris et al. (2012). Sample ( $0.2 \mathrm{~mL})$ at concentration of $20 \mathrm{mg}$ $\mathrm{mL}^{-1}$ was mixed with $1.5 \mathrm{~mL}$ of the diluted Folin-Ciocalteau reagent (1:2). The resulting solution was maintained during $5 \mathrm{~min}$ at room temperature $\left(25^{\circ} \mathrm{C}\right)$. Then, $60 \mathrm{~g} \mathrm{~L}^{-1}$ sodium bicarbonate solution (1.5 $\mathrm{mL}$ ) was added to the mixture and incubated for $90 \mathrm{~min}$ at room temperature. The sample absorbance was evaluated spectrophotometrically at wavelength $750 \mathrm{~nm}$. Methanolic solutions of gallic acid with concentration ranging from 25 to $150 \mathrm{mg} \mathrm{L}^{-1}$ were used as a standard in an appropriate calibration curve $\left(\mathrm{y}=0.0042 \mathrm{x}+0.0713 ; \mathrm{R}^{2}=0.97\right.$; where $y$ and $x$ were the absorbance and concentration of gallic acid, respectively). The results were expressed as $\mathrm{mg}$ gallic acid equivalent (G.A.E.) $\mathrm{g}^{-1}$ of mushroom flour or protein concentrate.

\subsection{2. $D P P H$ radical scavenging activity}

The DPPH assay was performed to evaluate the radical scavenging ability (RSA) of mushroom flour and protein concentrate, according to the procedure described by Coelho, Aquino, Latorres, \& Salas-Mellado (2019). A sample $(0.4 \mathrm{~mL})$ at concentration of $20 \mathrm{mg} \mathrm{mL}^{-1}$ was added to $0.4 \mathrm{~mL}$ of $0.2 \mathrm{mmol} \mathrm{L}^{-1} \mathrm{DPPH}^{+}$and mixed vigorously. The resulting solution was incubated at $25{ }^{\circ} \mathrm{C}$ for $45 \mathrm{~min}$ in the dark before the analysis. The absorbance of the samples was measured at wavelength $515 \mathrm{~nm}$. The DPPH scavenging ability was calculated according to a Trolox calibration curve $\left(y=-0.0002 x+0.1543 ; R^{2}=0.95\right.$; where $y$ and $\times$ are the absorbance and concentration of Trolox, respectively).

The radical inhibition rate was assessed by Equation 2 .

InhibitionRate $(\%)=\left\langle 1-\left(\frac{A_{\text {sample }}}{A_{\text {control }}}\right)\right\rangle x 100$

where $A_{\text {sample }}$ is the absorbance value of the sample and $A_{\text {control }}$ is the absorbance value of the control.

The results of radical scavenging ability were expressed as $I C_{50}$. Namely, the amount of antioxidant required to reduce the concentration of the free radical by $50 \%$ and was estimated as follows:

$I C_{50}=\left(\frac{C_{\text {sample }}}{I R}\right) x 50$

where $C_{\text {sample }}$ is the concentration of antioxidants in the sample (determined by the Trolox calibration curve formula) and $I R$ is the inhibition rate of the sample (determined by Equation 2).

Aditionally, the $\mathrm{IC}_{50}$ of Trolox $(10.81 \pm 0.1$ for DPPH and $23.15 \pm$ 4.0 for ABTS) was used to calculate the Trolox Equivalent Antioxidant Capacity (TEAC) of the samples by using Equation 4 (Ferreira-Santos et al., 2020):

$T E A C=\left(\frac{I C_{50} \text { Trolox }}{I I C_{50} \text { Sample }}\right)$

The higher TEAC value means the higher RSA.

\subsubsection{ABTS radical scavenging assay}

The ABTS $^{+}$scavenging activity was determined according to the method used by Coelho et al. (2019). Briefly, $7 \mathrm{mmol} \mathrm{L}{ }^{-1}$ ABTS solution was dispersed in $2.45 \mathrm{mmol} \mathrm{L}^{-1}$ potassium persulfate (at $1: 1$ ratio). Then, the resulting solution was stored for $16 \mathrm{~h}$ at room temperature $\left(25^{\circ} \mathrm{C}\right)$ in dark conditions. The ABTS solution was diluted in ethanol in order to achieve ABTS absorbance value of 0.70 , at a wavelength of $734 \mathrm{~nm}$. Afterward, ABTS radical solution $(0.6 \mathrm{~mL})$ was added to $0.2 \mathrm{~mL}$ of mushroom flour or protein concentrate solution, both in the concentration of $20 \mathrm{mg} \mathrm{mL}^{-1}$. An accurate determination of absorbance value was performed in a spectrophotometer at wavelength $734 \mathrm{~nm}$ started after $5 \mathrm{~min}$. An appropriate calibration curve was used with Trolox as a standard $\left(y=-0.0002 x+0.1543 R^{2}=0.95\right.$; where $y$ and $\times$ were the absorbance and concentration of Trolox, respectively). The rate of inhibition of the $\mathrm{ABTS}^{+}$radical was determined using Equation 2.

\subsection{Gastrointestinal digestion}

\subsubsection{In vitro digestion of protein concentrate and mushroom flour}

The in vitro digestion experiment was performed as previously described by Nobre et al. (2018). The procedure was based on the harmonized INFOGEST in vitro digestion protocol to simulate the oral, gastric, and intestinal conditions (Minekus et al., 2014). Samples (5 mL) were prepared by dispersing $20 \mathrm{mg} \mathrm{mL}^{-1}$ protein concentrate or mushroom flour in deionized water and stored at refrigeration temperature $\left(5^{\circ} \mathrm{C}\right)$ overnight to ensure the sample full rehydration.

Oral phase simulation consisted in the addition of simulated salivary fluid (SSF) ( $\mathrm{KCl} 15.1 \mathrm{mmol} \mathrm{L}^{-1}, \mathrm{KH}_{2} \mathrm{PO}_{4} 3.7 \mathrm{mmol} \mathrm{L}^{-1}, \mathrm{NaHCO}_{3} 13.6$

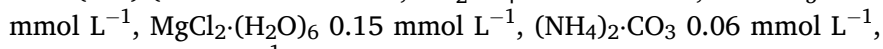
and $\left.\mathrm{HCl} 1.1 \mathrm{mmol} \cdot \mathrm{L}^{-1}\right), \mathrm{CaCl}_{2} \cdot\left(\mathrm{H}_{2} \mathrm{O}\right)_{2}$ (to reach the concentration of 1.5 $\mathrm{mmol} \mathrm{L} \mathrm{L}^{-1}$ ), and $\alpha$-amylase enzyme solution (to obtain $75 \mathrm{U} \mathrm{mL}^{1}$ activity). Samples $(5 \mathrm{~mL})$ were incubated for $2 \mathrm{~min}$ at $37^{\circ} \mathrm{C}$ in a water bath under constant shaking (120 horizontal strokes per minute).

The stomach conditions were mimicked by the addition of simulated gastric fluid (SGF) (KCl $6.9 \mathrm{mmol} \mathrm{L}^{-1}, \mathrm{KH}_{2} \mathrm{PO}_{4} 0.9 \mathrm{mmol} \mathrm{L}^{-1}, \mathrm{NaHCO}_{3}$ $25 \mathrm{mmol} \mathrm{L}^{-1}, \mathrm{NaCl} 47.2 \mathrm{mmol} \mathrm{L}^{-1}, \mathrm{MgCl}_{2} \cdot\left(\mathrm{H}_{2} \mathrm{O}\right)_{6} 0.1 \mathrm{mmol} \mathrm{L}^{-1}$, $\left(\mathrm{NH}_{4}\right)_{2} \cdot \mathrm{CO}_{3} 0.5 \mathrm{mmol} \mathrm{L}^{-1}$ and $\left.\mathrm{HCl} 15.6 \mathrm{mmol} \mathrm{L}-1\right), \mathrm{CaCl}_{2} \cdot\left(\mathrm{H}_{2} \mathrm{O}\right)_{2}$ (to achieve the concentration of $0.15 \mathrm{mmol} \mathrm{L}^{-1}$ in the fluid), and porcine pepsin solution (with an activity of $2000 \mathrm{U} \mathrm{mL}^{-1}$ in the final mixture). The $\mathrm{pH}$ value was adjusted to 3.0 with $1 \mathrm{~mol} \mathrm{~L}^{-1} \mathrm{HCl}$, and the gastric phase volume was complete with milli-Q water. The samples were incubated in a shaking water bath at $37{ }^{\circ} \mathrm{C}$ during $2 \mathrm{~h}$.

The intestinal phase conditions were mimicked by the addition of simulated intestinal fluid (SIF) ( $\mathrm{KCl} 6.8 \mathrm{mmol} \mathrm{L}^{-1}, \mathrm{KH}_{2} \mathrm{PO}_{4} 0.8 \mathrm{mmol}$ $\mathrm{L}^{-1}, \mathrm{NaHCO}_{3} 85 \mathrm{mmol} \mathrm{L}-1, \mathrm{NaCl} 38.4 \mathrm{mmol} \mathrm{L}^{-1}, \mathrm{MgCl}_{2} \cdot\left(\mathrm{H}_{2} \mathrm{O}\right)_{6} 0.33$ $\mathrm{mmol} \mathrm{L}{ }^{-1}$, and $\mathrm{HCl} 8.4 \mathrm{mmol} \mathrm{L}^{-1}$ ), $\mathrm{CaCl}_{2} \cdot\left(\mathrm{H}_{2} \mathrm{O}\right)_{2}$ (to obtain $0.6 \mathrm{mmol} \mathrm{L}^{-1}$ in the fluid), pancreatin suspension (with an activity of $100 \mathrm{U} \mathrm{mL}^{-1}$ in the final mixture) and bile solution (to obtain $10 \mathrm{mmol} \mathrm{L}^{-1}$ in the final mixture), both prepared in SIF solution. The $\mathrm{pH}$ value was adjusted to 7.0 with $1 \mathrm{~mol} \mathrm{~L}^{-1} \mathrm{NaOH}$, when necessary. Samples were incubated in the shaking water bath at $37^{\circ} \mathrm{C}$ for $2 \mathrm{~h}$. At the end of the intestinal phase, the reaction was stopped by adding $1 \mathrm{mmol} \mathrm{L}^{-1}$ of enzyme inhibitor pefabloc ${ }^{\circledR}$ SC.

Samples were collected after the oral phase, every $30 \mathrm{~min}$ during gastric and intestinal phases, and cooled in ice before measurements. All samples were tested at least in triplicate.

\subsubsection{Protein hydrolysis degree during in vitro digestion}

The protein hydrolysis degree $(H D)$ of mushroom flour and protein concentrate during in vitro digestion was performed according to Simões, Martins, Pinheiro, Vicente, \& Ramos (2020) procedure. Briefly, a sample $(0.5 \mathrm{~mL})$ of each in vitro digestion phase was diluted in $0.1 \mathrm{~mol}$ $\mathrm{L}^{-1} \mathrm{NaHCO}_{3}$ at $\mathrm{pH} 8.5$ to achieve a final protein concentration range from 0.05 to $0.2 \mathrm{mg} \mathrm{mL}^{-1}$. Afterward, $0.25 \mathrm{~mL}$ of $0.1 \%$ TNBSA was added to the resulting solution $(0.5 \mathrm{~mL})$ and incubated at $37^{\circ} \mathrm{C}$ during 2 $\mathrm{h}$ with gentle agitation. Subsequently, $0.25 \mathrm{~mL}$ of $10 \%$ SDS and 0.125 $\mathrm{mL}$ of $1 \mathrm{~mol} \mathrm{~L}^{-1} \mathrm{HCl}$ were added to each sample and homogenized. Taking into consideration the potential interference of the pepsin from 
the gastric juice and pancreatin from intestinal phase on the measurements, an in vitro digestion without sample was performed and used as blank.

Samples $(0.2 \mathrm{~mL})$ were transferred to a 96-well microplate and the absorbance measurements were carried out at wavelength $335 \mathrm{~nm}$. All samples were analyzed in triplicate.

The free amino groups content was determined using serine standard curve $\left(\mathrm{y}=0.226 \mathrm{x}+0.2431 ; \mathrm{R}^{2}=0.98\right.$; where $y$ and $x$ were the absorbance and serine concentration, respectively). The $H D$ was estimated according to the percentage of peptide bonds cleaved in the total number of peptide bonds using the following equation:

$H D(\%)=\left(\frac{h_{\text {sample }}}{h_{\text {total }}}\right) \times 100$

where $h_{\text {sample }}$ is the number of peptide bonds cleaved in sample after each in vitro digestion phase and $h_{\text {total }}$ is the total number of peptide bonds in the sample after the intestinal phase.

\subsection{Statistical procedures}

All experiments were carried out at least in triplicate and data were expressed as the average \pm standard deviation (SD). One-way analysis of variance (ANOVA) was carried out coupled with Tukey mean comparison test with a significance level of $5 \%$ using Statistica ${ }^{\circledR}$ software version 7.0 (Statsoft, USA). Results were considered significantly different for $p$-values $\leq 0.05$.

\section{Results and discussion}

\subsection{Optimization of the protein concentration process}

The protein extraction process from mushroom flour is influenced by several factors, for instance, $\mathrm{pH}$ value, temperature, solvent type, solvent ratio, extraction time and ionic strength (Arango, Patiño, García, Calcedo, \& Guerrero, 2012). Several studies have demonstrated that the $\mathrm{pH}$ value and solvent ratio were the main factors that impacted the protein extraction yield (Firatligil-Durmus \& Evranuz, 2010; JarpaParra et al., 2014). Thus, its influence was herein studied.

\subsubsection{Effect of $p H$ on protein solubility}

Results obtained regarding the influence on mushroom flour protein solubility by adjusting the supernatant to various $\mathrm{pH}$ values are shown in
Fig. 1. The solubility of the protein varied between $0.035 \pm 0.005$ and $0.51 \pm 0.02 \mathrm{mg} \mathrm{mL}^{-1}$. The results showed that by increasing the $\mathrm{pH}$ value from 4.0 to 12.0 , the protein solubility of mushroom flour also increased. The lowest protein solubility was achieved for samples at $\mathrm{pH}$ between 3.0 and 4.0, namely $0.065 \pm 0.005$ and $0.035 \pm 0.005 \mathrm{mg}$ $\mathrm{mL}^{-1}$, respectively. This $\mathrm{pH}$ range is relatively close to the isoelectric point, at which the protein net load is close to zero and the repulsive electrostatic force is weakened. Consequently, the solubility of the protein tends to decrease and precipitate (Simões, Araújo, Vicente, \& Ramos, 2020). These observations agree with those reported by CruzSolorio et al. (2014), which by alkaline extraction and isoelectric precipitation of the protein obtained from three strains of Pleurotus spp., identified an isoelectric point in a range between $\mathrm{pH} 3.96$ and 4.15.

The maximum protein solubility of $0.51 \pm 0.02 \mathrm{mg} \mathrm{mL}^{-1}(p \leq 0.05)$ was reached at pH 12 (Fig. 1). A high net load is achieved by the proteins at alkaline environments, which results in higher protein solubility. In addition, it has been reported that high alkaline concentrations contribute to the breakdown of hydrogen bonds and to the dissociation of hydrogen from sulfate and carbonyl groups (Hadidi, Khaksar, Pagan, \& Ibarz, 2019; Jarpa-Parra et al., 2014). These results are also in agreement with those reported by Cruz-Solorio et al. (2014), who observed a maximum protein solubility of a Pleurotus flour by adjusting the $\mathrm{pH}$ value to 12 . Thus, $\mathrm{pH} 12$ was selected as the optimal for protein extraction as it promotes protein solubility, and $\mathrm{pH} 4$ was chosen for the precipitation phase because at this $\mathrm{pH}$ the net load decreases and the proteins tend to aggregate and precipitate, allowing a better separation from the rest of the compounds present in the solution.

\subsubsection{Effect of mushroom flour-solvent ratio on protein extraction yield}

The effect of the mushroom flour-solvent ratio on the protein extraction yield is shown in Fig. 2. The solubility of the protein varied from $5.4 \pm 0.2$ to $9.7 \pm 0.2 \mathrm{mg} \mathrm{mL}^{-1}(p \leq 0.05)$. The yield was estimated by Equation 1 (section 2.3.2). Considering the initial protein content of the mushroom flour of $32 \%$ d.w. (section 3.2 ), a protein extraction yield of $17 \%, 25 \%$ and $30 \%$ was determined for extractions using $1: 5,1: 10$ and 1:20 solvent ratios, respectively.

Results showed that the protein yield increases with the amount of solvent applied to the mushroom flour. Significant differences were found for assays where the mushroom flour-solvent ratio varied from 1:5 to $1: 20(p \leq 0.05)$. While when increasing the ratio from $1: 5$ to $1: 10$ and from 1:10 to 1:20 no significant differences were found on the protein solubility.

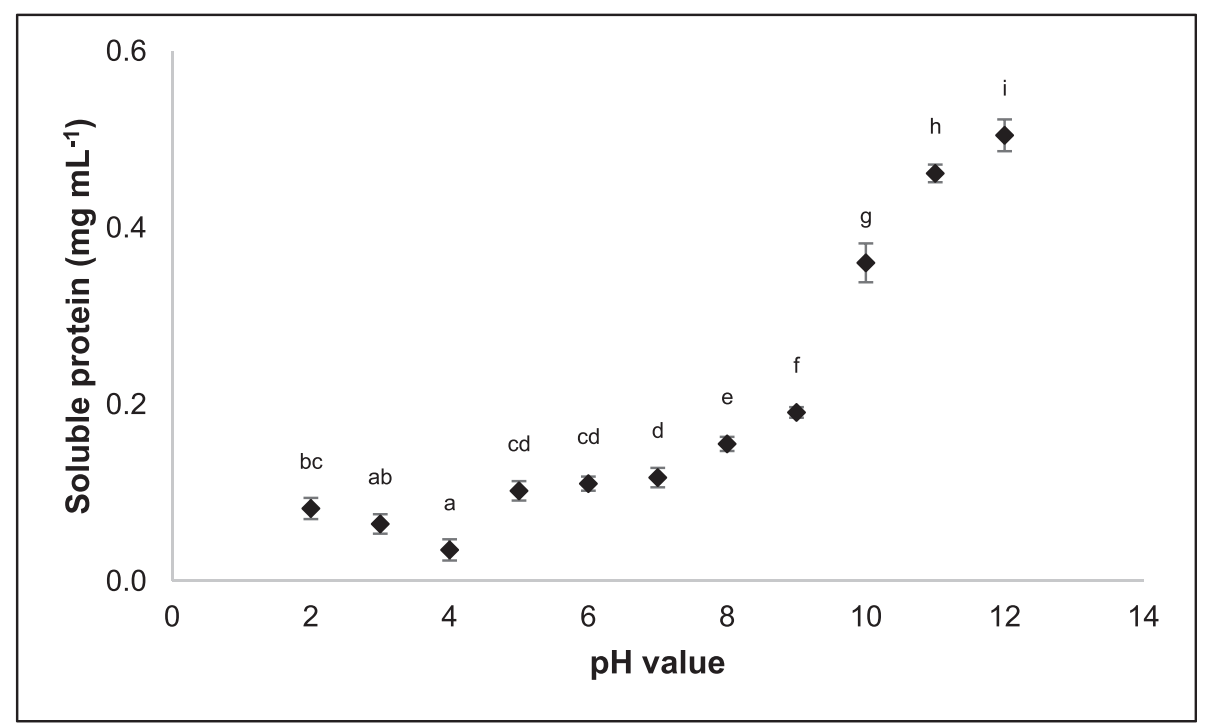

Fig. 1. Effect of the $\mathrm{pH}$ on the protein solubility. Results are given as mean \pm standard deviation. Different superscript letters correspond to significantly different solubility $(p \leq 0.05)$. 


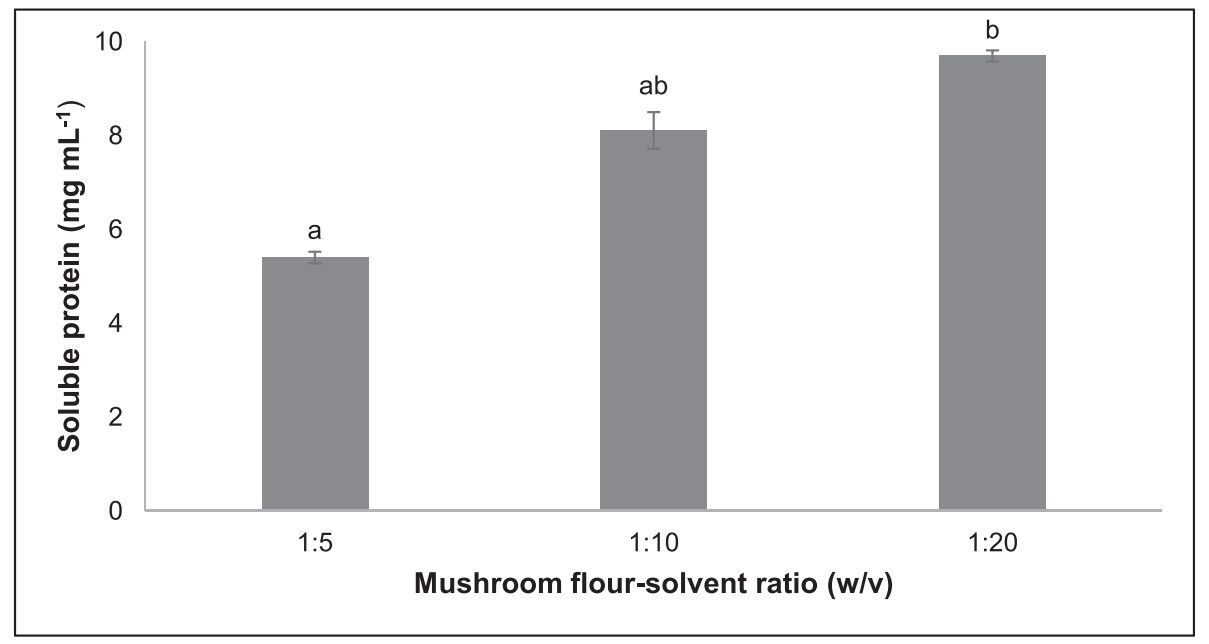

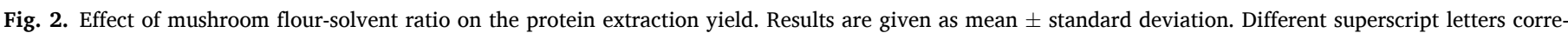
spond to significantly different solubility $(p \leq 0.05)$

According to literature, by increasing the solvent ratio, the mass transfer coefficient is enhanced. Results showed that the diffusivity of the solvent in the solid and the protein desorption improve, resulting in a better extraction of protein (Arango et al., 2012; Hadidi et al., 2019). Results achieved in this study were in the same line of those observed in the literature. For example, in a study where a protein concentrate from Erythrina edulis flour was obtained, the protein yield raised by increasing the flour-solvent ratio from 1:20 to 1:40 (Arango et al., 2012). In another study, aiming at extract alfalfa protein, it was observed that by increasing the flour-solvent ratio from 1:20 to 1:45 (w/v) an enhanced extraction yield and protein content was obtained (Hadidi et al., 2019).

Based on the best results obtained, considering the effect of $\mathrm{pH}$ in the protein solubility and the mushroom flour-solvent ratio on the protein yield, a pH value of 12 and 4 were selected for the extraction and precipitation phases, respectively, and a 1:20 (w/v) mushroom floursolvent ratio was selected for the extractions. These conditions were applied in the further experiments.

\subsection{Proximate composition of mushroom flour and protein concentrate}

The nutritional value of mushrooms, as well as its bioactive compounds content, change according to the species, strain, the stage of maturation, the substrate and the growing conditions used (Bach et al., 2017; Valverde, Hernández-Pérez, \& Paredes-López, 2015). Table 1 shows the proximate composition of $P$. ostreatus mushroom flour and protein concentrate.

The lipid content obtained for the mushroom flour $(1.9 \pm 0.1 \%$ d.w. $)$ was similar to those reported for $P$. ostreatus fruiting bodies cultivated on printed paper $(1.68 \pm 0.49 \%$ d.w. $)$ or olive press cake $(1.64 \pm 0.35 \% \mathrm{~d}$. w.) (Fernandes, Barros, Martins, Herbert \& Ferreira, 2015; Koutrotsios, Mountzouris, Chatzipavlidis, \& Zervakis, 2014). The lipid content of

Table 1

Proximate composition of mushroom flour and protein concentrate in \% dry weight.

\begin{tabular}{lll}
\hline & Mushroom flour & Protein concentrate \\
\hline Lipids & $1.9 \pm 0.1^{\mathrm{a}}$ & $7.1 \pm 0.5^{\mathrm{b}}$ \\
Protein & $32 \pm 1^{\mathrm{a}}$ & $57 \pm 2^{\mathrm{b}}$ \\
Carbohydrates & $50.5 \pm 0.2^{\mathrm{a}}$ & $20.0 \pm 0.4^{\mathrm{b}}$ \\
Crude fiber & $5.6 \pm 0.5^{\mathrm{a}}$ & $0.5 \pm 0.1^{\mathrm{b}}$ \\
Moisture & $5.6 \pm 0.3^{\mathrm{a}}$ & $6.5 \pm 0.9^{\mathrm{a}}$ \\
Ash & $9.9 \pm 0.2^{\mathrm{a}}$ & $9.4 \pm 0.3^{\mathrm{a}}$ \\
\hline
\end{tabular}

NOTE: Results are given as mean \pm standard deviation. Different superscript letters correspond to significantly different values $(p \leq 0.05)$.
P. ostreatus mushrooms is generally low, ranging from 0.5 to $7.6 \%$ d.w. (Carrasco-González, Serna-Saldivar, \& Gutierrez Uribe, 2017). Nevertheless, it contains essential fatty acids, such as oleic, linoleic and linolenic acids, which take part in a wide range of physiological functions, such as the prevention of cardiovascular diseases and arthritis, the decrease of triglyceride levels and blood pressure, and the promotion of brain, eye and heart health (Majesty, Ijeoma, Winner, \& Prince, 2019; Valverde et al., 2015). Edible mushrooms mostly contain polyunsaturated fatty acids, thus, its regular intake may contribute to the reduction of serum cholesterol. The major sterol produced by edible mushrooms is ergosterol, a precursor of vitamin $D_{2}$, which has antioxidant properties and prevents cardiovascular diseases (Valverde et al., 2015). Foods with low-fat content, such as Pleurotus mushrooms, are suitable for healthy and calorie restriction diets.

The lipid density of the mushroom flour significantly increased by $274 \%$ after concentrating the protein $(p \leq 0.05)$. The high lipid content found in the protein concentrate can be explained by the binding mechanism between protein and lipids, which results in the emulsification of the lipids by the protein (Cruz-Solorio et al., 2014).

The protein content of the mushroom flour grown on sorghum forage ( $32 \pm 1 \%$ ) was close to the values reported for $P$. ostreatus mushroom grown on spent beer grain with wheat bran $(32.4 \pm 0.1 \%)$ or in almond and walnut shells $(31.36 \pm 0.57 \%)$ (Lavelli et al., 2018). These three substrates seem to result in similar protein content of the harvested mushrooms. Nevertheless, the protein values reported for $P$. ostreatus varies between $7.3 \%$ and $53.3 \%$ (Carrasco-González et al., 2017). The protein content of the substrate affects the final concentration in the mushroom fruiting bodies. Substrates such as spent beer grains, wheat bran and wheat stalk are reported to result in high-protein mushrooms (Lavelli et al., 2018). Also, post-harvest treatments, such as the irradiation of a low dosage of gamma rays (1 kGy or less) on the fruiting bodies have shown to be an effective strategy to increase protein content by $37 \%$ (Carrasco-González et al., 2017).

The protein density of the protein concentrate increased by $78 \%$ as compared with the unprocessed mushroom flour. In other foodstuffs, such as flaxseed meal and sour cherry kernel, an increase in protein density of $49.6 \%$ and $91.3 \%$, respectively, of the resulting protein concentrates as compared with their defatted flours was observed. These protein concentrates were also obtained by alkaline extraction and isoelectric precipitation (Tirgar, Silcock, Carne \& Birch, 2017; Çelik, Güzel \& Yildirim, 2019). This selective method separates the protein from insoluble residues resulting in significantly higher protein density in the protein concentrate $(p \leq 0.05)$ (Simões, Araújo et al., 2020).

The carbohydrate content of $P$. ostreatus have been reported in a 
range between 13.1 and $85.8 \%$ d.w. (Carrasco-González et al., 2017). This large variability may be related to genetic factors involved in the determination of the amount and type of saccharides present in the fungal cell wall. In this work, for the mushroom flour, a carbohydrate content of $50.5 \pm 0.2 \%$ was determined, which is also in agreement with results found for a white oyster type of $P$. ostreatus ( $46.62 \pm 0.92 \%$ dry matter) (Bach et al., 2017).

Most of the carbohydrates of $P$. ostreatus are polysaccharides that comprise the cell wall, such as $\alpha$ - and $\beta$-glucans, chitin and hemicelluloses (mannans, xylans and galactans). These polysaccharides are not digestible and are considered as a source of dietary fiber (Bach et al., 2017). The main fiber source in the edible mushrooms are the $\beta$-glucans, which have been associated with anticarcinogenic properties and immunoregulatory functions ( $\mathrm{Zhu}, \mathrm{Du}, \mathrm{Bian} \& \mathrm{Xu}, 2015$ ). A crude fiber content of $5.6 \pm 0.5 \%$ was determined in the mushroom flour.

The carbohydrates and crude fiber content significantly decreased on the protein concentrate, as compared with mushroom flour $(p \leq 0.05)$. While total carbohydrates decreased by $60 \%$, the crude fiber was almost residual in the protein concentrate. The harsh conditions used during the concentration of the protein, namely the extreme alkaline and acidic conditions, may disrupt the cell wall of the mushroom, which is mainly composed of polysaccharides, such as chitin and glucans. Acid $\mathrm{pH}$ below 4.1 can cause hydrolysis of cell wall macromolecules. (Zivanovic, Buescher \& Kim, 2003), while alkaline treatment can deacetylate and degrade chitin in the cell wall, improving its solubility and making it easier to remove (Pillai, Paul \& Sharma 2009). On the other hand, adjusting the $\mathrm{pH}$ to the isoelectric point allows the selective precipitation of the protein, separating it from the rest of the soluble components in the solution, including carbohydrates and fiber.

The amount of minerals available in the growth substrates affects the final mineral level present in the mushroom (Lavelli et al., 2018). Ash content ranges from 4.1 to $15.9 \%$ d.w. in P. ostreatus (Carrasco-González et al., 2017) and its related to the presence of nutritionally important minerals. The main fraction of minerals available in mushrooms is constituted by potassium, phosphorus, and magnesium (Bach et al., 2017). The protein concentrate maintained the same moisture and ash content initially present in the mushroom flour (around 6 to $9 \%$ ), without significant changes $(p>0.05)$.

\subsection{Soluble protein composition}

Mushrooms produce a large number of proteins with biological and pharmacological activities (Al-Obaidi, 2016). The determination of the molecular weight of the peptides that comprise the protein concentrate may provide an overview regarding those properties. The SDS-PAGE profile of the soluble protein from the concentrated sample is shown in Fig. 3.

Electrophoresis profile of the protein concentrate sample (analyzed in duplicate) revealed molecular weight $\left(M_{W}\right)$ bands of $12,13,28,32$ and $35 \mathrm{kDa}$ (Fig. 3).

The $M w$ bands found on the protein concentrate sample may correspond to several valuable proteins from $P$. ostreatus, which have been reported in the literature. For example, hydrophobins, which have a $M w$ ranging from 10 to $20 \mathrm{kDa}$, these proteins are useful for reversing surface hydrophobicity, stabilizing emulsions and as a coating for biomaterials (Cox \& Hooley, 2009; Erjavec et al., 2012). The $M w$ bands ranging from 9 to $15 \mathrm{kDa}$ in the protein concentrate samples may be also attributed to pleurostrin, a unique peptide from $P$. ostreatus mushrooms, with antifungal properties against several plant pathogenic fungi (e.g. Michospaerella arachidicola, Fusarium oxysporum and Physalospora piricola) (Alves et al., 2013; Erjavec et al., 2012). Additionally, it has also been reported the presence of lectins ( $M w$ bands ranging from 12 to $190 \mathrm{kDa}$ ) and ribonucleases $(M w$ bands ranging from 8 to $18 \mathrm{kDa}$ and from 28 to $45 \mathrm{kDa}$ ) in several mushrooms, including $P$. ostreatus, these peptides have been mainly recognized by their antitumor and antiproliferative activities (Erjavec et al., 2012; Xu et al., 2011).

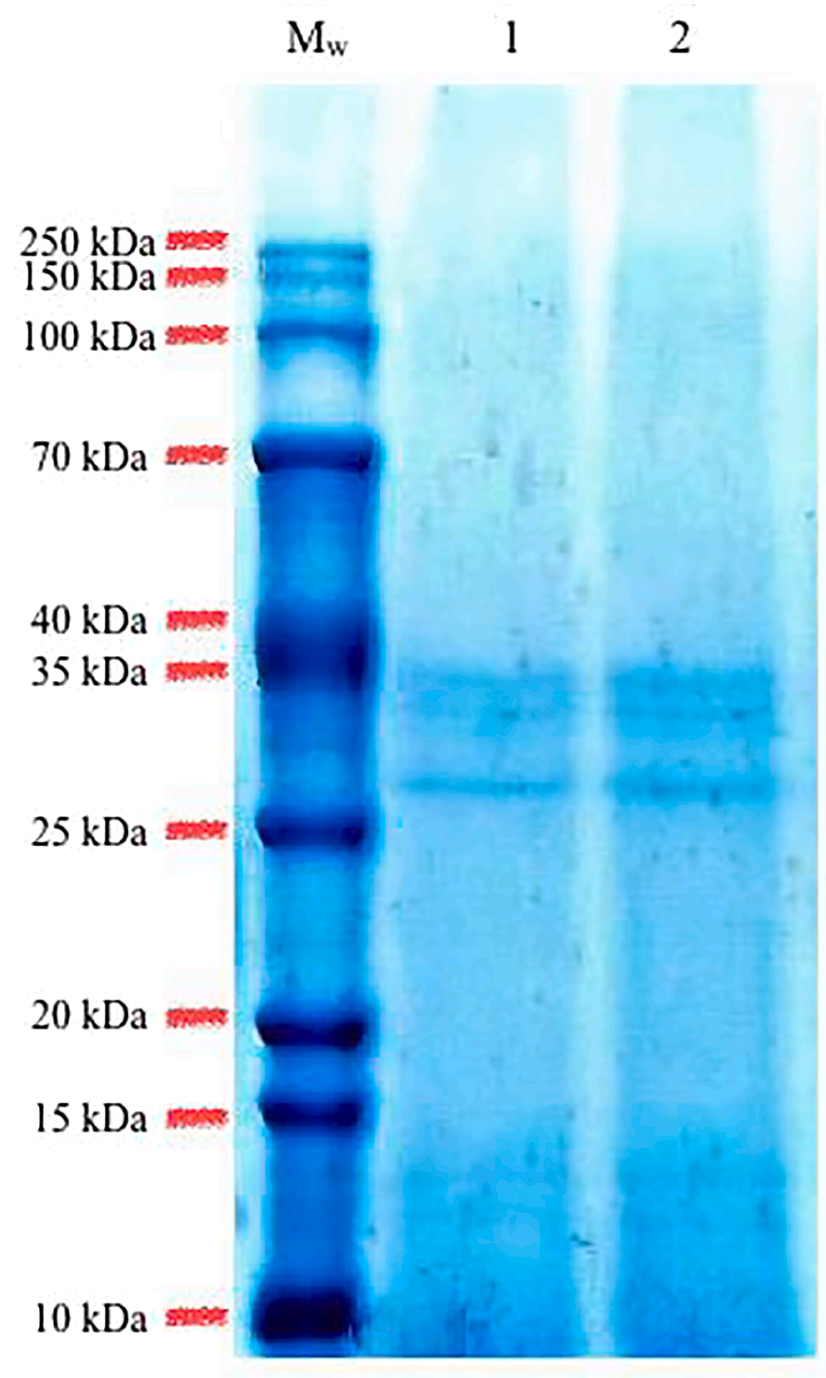

Fig. 3. SDS-PAGE pattern of the protein concentrate sample $(1,2) . M_{w}$ : Standard marker Bio-Basic ${ }^{\circledR}$.

\subsection{Antioxidant activity}

Results obtained on the antioxidant activity of the mushroom flour and the protein concentrate, given by its total phenolic content and, DPPH and ABTS assays, are shown in Table 2.

The DPPH methodology is based on the principle of reducing the DPPH radical to DPPH-H, after link with a substance acting as hydrogen atom donor. Results showed that the mushroom flour and the protein concentrate had a similar effect inhibiting the formation of DPPH-H ( $p$ $>0.05)$.

Table 2

Total phenolic content (TPC), DPPH and ABTS radical scavenging activity of mushroom flour and protein concentrate.

\begin{tabular}{|c|c|c|c|c|c|}
\hline & \multirow{2}{*}{$\begin{array}{l}\text { TPC } \\
(\mathrm{mg} \\
\text { GAE } \\
\left.\mathrm{g}^{-1}\right)\end{array}$} & \multicolumn{2}{|l|}{ DPPH } & \multicolumn{2}{|l|}{ ABTS } \\
\hline & & $\begin{array}{l}\mathrm{IC}_{50}(\mathrm{mg} \\
\left.\mathrm{mL}^{-1}\right)\end{array}$ & TEAC & $\begin{array}{l}\mathrm{IC}_{50}(\mathrm{mg} \\
\left.\mathrm{mL}^{-1}\right)\end{array}$ & TEAC \\
\hline $\begin{array}{l}\text { Mushroom } \\
\text { flour }\end{array}$ & $36 \pm 1^{b}$ & $1.1 \pm 0.2^{\mathrm{a}}$ & $\begin{array}{l}10.03 \pm \\
0.3^{\mathrm{a}}\end{array}$ & $\begin{array}{l}13.2 \pm \\
0.2^{\mathrm{b}}\end{array}$ & $\begin{array}{l}1.75 \pm \\
0.1^{\mathrm{b}}\end{array}$ \\
\hline $\begin{array}{l}\text { Protein } \\
\text { concentrate }\end{array}$ & $\begin{array}{l}24.2 \pm \\
0.8^{\mathrm{a}}\end{array}$ & $1.4 \pm 0.2^{\mathrm{a}}$ & $\begin{array}{l}7.92 \pm \\
0.6^{\mathrm{a}}\end{array}$ & $\begin{array}{l}15.3 \pm \\
0.3^{\mathrm{a}}\end{array}$ & $\begin{array}{l}1.52 \pm \\
0.1^{\mathrm{a}}\end{array}$ \\
\hline
\end{tabular}

Results are given as mean \pm standard deviation. Different superscript letters correspond to significantly different values $(p \leq 0.05)$. 
A spectrophotometric method using ABTS radical is commonly used to estimate the total antioxidant activity of compounds. The ABTS scavenging ability of mushroom flour was significantly higher as compared to the protein concentrate $(p \leq 0.05)$ which is consistent with the results obtained for the content of phenolic compounds. Although both the DPPH and ABTS radical scavenging assays are useful to determine the antioxidant capacity of several compounds, it has been reported that the antioxidant capacity detected by the ABTS assay is mainly associated with the content of phenolic compound and flavonoids present in the sample, while the DPPH mainly reflects the presence of high-pigmented and hydrophilic antioxidants (Floegel et al., 2011). High amounts of flavonoids such as chrysin $\left(40 \mathrm{mg} 100 \mathrm{~g}^{-1}\right)$ and rutin (31.2 mg $100 \mathrm{~g}^{-1}$ ) have been detected in ethanolic extracts of $P$. ostreatus, as well as other compounds with antioxidant activity, including $\beta$-carotene (3.1 mg $100 \mathrm{~g}$-1), ascorbic acid (25 mg $100 \mathrm{~g}^{-1}$ ) and $\alpha$-tocopherol (30.3 mg $100 \mathrm{~g}^{-1}$ ) (Jayakumar et al., 2011). This suggests that the antioxidant compounds that decrease most in the protein concentrate are flavonoids and phenolic compounds, while hydrophilic (e.g. ascorbic acid) and highly pigmented antioxidants (e.g. carotenoids) remain almost unaffected.

It is important to find out whether the conditions used for obtaining the protein concentrate may alter its antioxidant activity. For example, when processing proteins, amino acid sequences which were embedded in the native protein may be released. These peptides, known as bioactive peptides, have positive health related effects, such as antioxidant activity and also others, e.g. they have been characterized as antimicrobial, hypocholesterolemic, antihypertensive and immunomodulatory (González et al., 2020; Li-Chan, 2015). On the other hand, as many of these compounds are sensitive to extreme temperatures, light or oxygen exposure, processing conditions can affect their antioxidant capacity (Ioannou, Chekir \& Ghoul, 2020). Low temperatures used during freezing can affect the antioxidant capacity. For example, in a study where the antioxidant capacity of $P$. ostreatus stored at different temperatures was assessed by DPPH radical scavenging method, as the temperature dropped (from 20 to $-40{ }^{\circ} \mathrm{C}$ ), the DPPH IC 50 increased (from 0.32 to $2.26 \mathrm{mg} \mathrm{mL}^{-1}$ ), showing a decrease in antioxidant activity (Bakir, Karadeniz, \& Unal, 2018). Also, the drying process might have an important effect on the phenolic content and the RSA. The freeze-drying process was reported to decrease the phenolic content and the DPPH IC $_{50}$ of $P$. ostreatus (Ucar \& Kardag, 2019). Considering that during its processing the protein concentrate was subjected to freezing and subsequent freeze-drying, this may somewhat explain its decrease in phenolic content and RSA as compared to the mushroom flour. However, phenolic compounds have been associated with a negative impact on protein digestion, since many of them may remain in the gastrointestinal tract inhibiting digestive enzymes (Cirkovic-Velickovic, \& Stanic-Vucinic, 2018). Thus, the removal of these compounds, which are beneficial to health but can also act as anti-nutrients, could mean better digestibility of the protein present in the concentrate.

\subsection{In vitro protein digestibility test}

The protein hydrolysis kinetic of the mushroom flour and the protein concentrate during in vitro gastrointestinal digestion, comprising oral, gastric and intestinal phase simulation, is shown in Fig. 4.

The behavior of protein hydrolysis during the digestion process depends strongly on the nature of the proteins present in the food, since each digestive enzyme has its specific site to hydrolyze. Pepsin is the enzyme responsible for the hydrolysis of proteins during the food passage through the stomach and has an affinity for breaking bonds between aromatic amino acids (Bhutta et al., 2013). The mushroom flour and the protein concentrate achieved a $H D$ of $16.5 \pm 2.5 \%$ and $20.3 \pm$ $3.1 \%$, respectively, after gastric digestion. The most remarkable increase in the protein $H D$ was observed for the protein concentrate sample, when passing from the gastric to the intestinal phase, reaching a $H D$ of $76.2 \pm 1.3 \%$. During intestinal digestion several proteolytic enzymes are secreted, such as trypsin, which cuts the internal bonds of lysine or arginine, the chymotrypsin breaks aromatic or neutral amino acid bonds, the elastase hydrolyzes aromatic amino acid bonds, while carboxypeptidases A and B cut aromatic amino acids and arginine or lysine from the C-ends of proteins and peptides, respectively (Bhutta et al., 2013). Subsequently, at the end of the intestinal phase, it was observed that $H D$ reached $100 \%$ for the protein concentrate $(p \leq 0.05)$. Most probably, the proteolytic enzymes present in the pancreatin completely digested the proteins from the concentrate into smaller peptides (Simões, Martins, et al., 2020). The full digestion of proteins facilitates its absorption into the bloodstream. On the other hand, the mushroom flour only reached a $H D$ of $23.5 \pm 4.6 \%$ at the end of the digestion. These results indicated that the protein digestibility of the protein concentrate was 4.2 -fold higher as compared with the mushroom flour $(p \leq 0.05)$. Limited digestibility of unprocessed flours compared to their respective protein concentrates or isolates may be due to the high content of nonprotein compounds, mainly polysaccharides, which hamper the accessibility to hydrolysis sites (Gbadamosi, Abiose \& Aluko, 2012). The

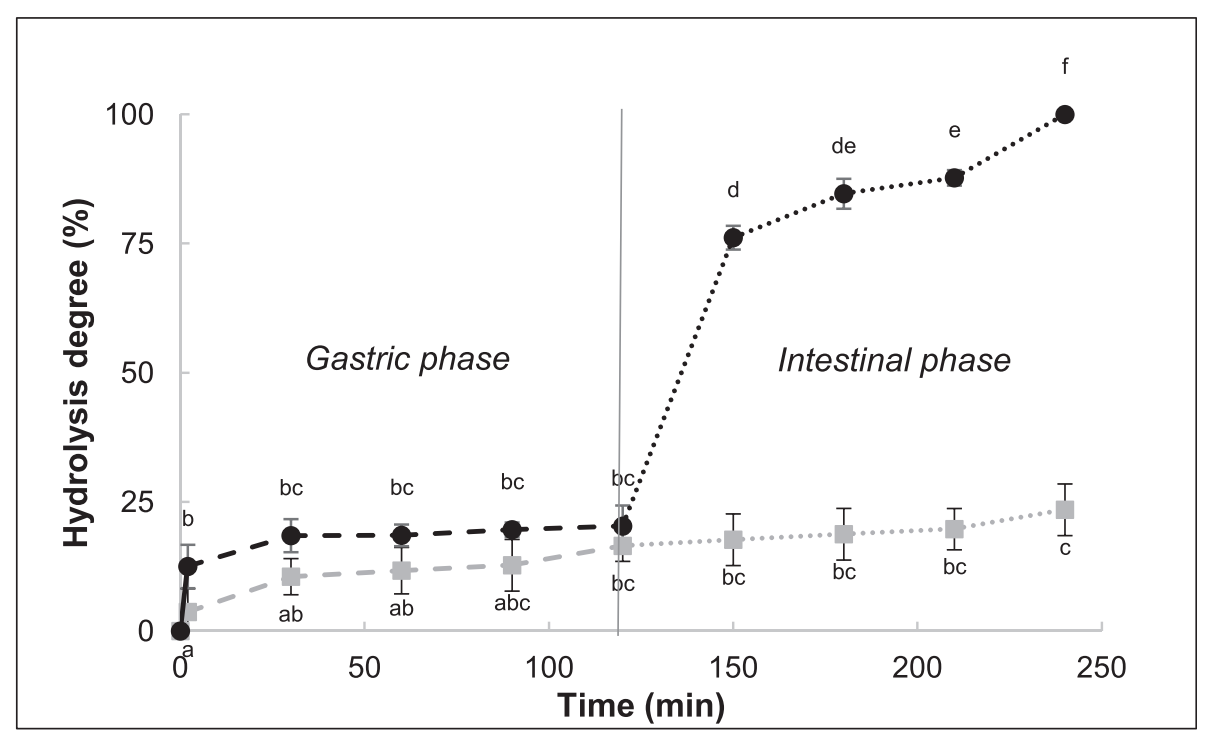

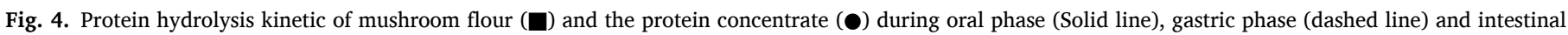
phase (dotted line). Results are given as mean \pm standard deviation. Different superscript letters correspond to significantly different values $(p \leq 0.05)$. 
partial denaturation of proteins during processing for obtaining the concentrate may have contributed to improved digestibility, since the alkaline treatment used for protein extraction can cause a partial denaturation of protein and promote its hydrolysis into smaller peptides, reducing its molecular size and increasing its solubility and diffusivity (Hadidi et al., 2019). The increase in protein digestibility is an indicator of the higher number of hydrolyzed peptide bonds and the availability of a higher number of hydrolysis sites (Aryee \& Boye, 2016). In accordance, a better $H D$ was also obtained for oil/whey protein emulsions with denatured proteins ( $80 \%)$ than in its native form (52\%). The authors suggested that denatured proteins were more sensitive to hydrolysis by intestinal proteases (Mat, Le Feunteun, Michon \& Souchon, 2016).

Although few studies report the in vitro digestibility of food proteins, to our knowledge, data on mushroom protein concentrates is limited, if not inexistent. Studies addressing the digestibility of protein concentrates or isolates from other food flours have systematically observed a significant increase in the digestibility rate of the protein, as compared to the digestion in the raw material. For example, $H D$ achieved at the end of the simulated digestion process for bean flour and its protein concentrate and isolate was $9.30,13.60$ and $28.29 \%$, respectively (Sathe, Iyer \& Salunkhe, 1982). Conophor nut flour enhanced the $H D$ from $52.28 \%$ to $73.47 \%$ in its protein isolate (Gbadamosi et al., 2012). And the $H D$ of a lentil protein isolate was $26 \%$ higher as compared to its raw flour (Aryee \& Boye, 2016). This shows that the purest forms of protein are likely to have higher digestibility than when attached to a large amount of non-protein compounds that hinder their hydrolysis by digestive enzymes. A higher hydrolysis degree allows a better digestion and bioavailability in the body, because shorter peptides (mainly di- and tri-peptides) are better absorbed by the enterocytes (Bhutta et al., 2013).

Complementary studies on the amino acids profile of the extracted protein mushroom will help to determine the quality of this protein source. Nevertheless, the great results obtained during in vitro gastrointestinal digestion supports its high potential for application in a wide variety of food products, such as protein fortified foods, vegan foods and specialized nutrition products for people with limited digestive function.

\section{Conclusions}

The protein concentrate from $P$. ostreatus mushroom flour was successfully obtained, eliminating most of the soluble non-protein compounds by extraction at $\mathrm{pH} 12$, followed by isoelectric precipitation at $\mathrm{pH} 4$, applying a 1:20 (w/v) mushroom flour-solvent ratio.

Regarding to antioxidant activity, the ABTS radical scavenging ability was significantly diminished, possibly due to the important decrease in the content of phenolic compounds. Nonetheless, the removal of phenolics is reported to have positive impact on protein digestibility.

In vitro digestion process demonstrated that the protein concentrate was completely hydrolyzed in the intestinal phase. The protein concentrate digestibility was enhanced 4.2-fold compared to mushroom flour, since the non-protein components that possibly hinder its hydrolysis by the digestive enzymes were removed.

The findings of this work suggest that the mushroom $P$. ostreatus in its form of protein concentrate has a promising potential to be incorporated into foods, improving their nutritional and functional value.

\section{CRediT authorship contribution statement}

Conceptualization: AG, RB, MC. Methodology: AC, LSS, CN. Validation: LSS, CN. Formal analysis: AG, AL, RMRJ, CN. Investigation: $\mathrm{CN}$, MC, RB. Resources: RB, MC, JT. Writing - original draft: AG. Writing review and editing: AG, CN, RB, MC. Visualization: JC, AL, RMRJ. Supervision: RB, CN, MC, JT. Project administration: RB. Funding acquisition: RB, JT, MC.

\section{Declaration of Competing Interest}

The authors declare that they have no known competing financial interests or personal relationships that could have appeared to influence the work reported in this paper.

\section{Acknowledgments}

This study was supported by the Portuguese Foundation for Science and Technology (FCT) under the scope of the strategic funding of UIDB/ $04469 / 2020$ unit and BioTecNorte operation (NORTE-01-0145-FEDER-000004) funded by the European Regional Development Fund under the scope of Norte 2020-Programa Operacional Regional do Norte and the Project ColOsH PTDC/BTM-SAL/30071/ 2017 (POCI-01-0145-FEDER-030071). The authors also acknowledge the grant for a postgraduate scholarship (CVU number 922722) provided by National Council of Science and Technology (CONACYT) México.

\section{References}

Al-Obaidi, J. R. (2016). Proteomics of edible mushrooms: A mini-review. Electrophoresis, 37(10), 1257-1263. https://doi.org/10.1002/elps.20160003.

Alves, M. J., Ferreira, I. C., Dias, J., Teixeira, V., Martins, A., \& Pintado, M. E. (2013). A review on antifungal activity of mushroom (basidiomycetes) extracts and isolated compounds. https://doi.org/10.2174/15680266113136660191.

Arango, O., Patiño, V., García, D., Calcedo, M., \& Guerrero, Y. (2012). Obtaining a protein extract from chachafruto flour (Erythrina edulis). Universidad y Salud, 14(2), $161-167$.

Aryee, A. N., \& Boye, J. I. (2016). Improving the digestibility of lentil flours and protein isolate and characterization of their enzimatically prepared hydrolysates. International Journal of Food Properties, 19(12), 2649-2665. https://doi.org/ 10.1080/10942912.2015.1123269.

Association of Official Analytical Chemists. (1995). Official methods of analysis of AOAC International.

Bach, F., Helm, C. V., Bellettini, M. B., Maciel, G. M., \& Haminiuk, C. W. I. (2017). Edible mushrooms: A potential source of essential amino acids, glucans and minerals. International Journal of Food Science \& Technology, 52(11), 2382-2392. https://doi. org/10.1111/ijfs.13522.

Bakir, T., Karadeniz, M., \& Unal, S. (2018). Investigation of antioxidant activities of Pleurotus ostreatus stored at different temperatures. Food Sci Nutr, 6(4), 1040-1044. https://doi.org/10.1002/fsn3.644.

Bhutta, Z. A., Sadiq, K., \& Aga, T. (2013). Protein digestion and bioavailability. In Encyclopedia of Human. Nutrition, 4, 116-122. https://doi.org/10.1016/B978-0-12375083-9.00240-3.

Carrasco-González, J. A., Serna-Saldívar, S. O., \& Gutiérrez-Uribe, J. A. (2017). Nutritional composition and nutraceutical properties of the Pleurotus fruiting bodies: Potencial use as food ingredient. Journal of Food Composition and Analysis, 58, 69-81. https://doi.org/10.1016/j.jfca.2017.01.016.

Çelik, M., Güzel, M., \& Yildirim, M. (2019). Effect of pH on protein extraction from sour cherry kernels and functional properties of resulting protein concentrate. Journal of Food Science and Technology, 56(6), 3023-3032. https://doi.org/10.1007/s13197019-03785-8.

Cirkovic Velickovic, T. D., \& Stanic-Vucinic, D. J. (2018). The Role of Dietary Phenolic Compounds in Protein Digestion and Processing Technologies to Improve Their Antinutritive Properties: Phenolic compounds in protein digestion.... Comprehensive Reviews in Food Science and Food Safety, 17(1), 82-103. https://doi.org/10.1111/ 1541-4337.12320.

Coelho, M. S., de Araujo Aquino, S., Machado Latorres, J., \& de las Mercedes SalasMellado, M. (2019). In vitro and in vivo antioxidant capacity of chia protein hydrolysates and peptides. Food Hydrocolloids, 91, 19-25. https://doi.org/10.1016/j. foodhyd.2019.01.018.

Cox, P. W., \& Hooley, P. (2009). Hydrophobins: New prospects for biotechnology. Fungal Biology Reviews, 23(1-2), 40-47. https://doi.org/10.1016/j.fbr.2009.09.001.

Cruz-Solorio, A., Garín-Aguilar, M. E., Leal-Lara, H., Ramírez-Sotelo, M. G., \& Valenciadel Toro, G. (2014). Proximate composition of Pleurotus fruit body flour and protein concentrate. Journal of Chemical, Biological and Physical Sciences, 5, 52-60. https:// doi.org/10.1007/s13197-018-3312-x.

Erjavec, J., Kos, J., Ravnikar, M., Dreo, T., \& Sabotič, J. (2012). Proteins of higher fungi from forest to application. Trends in Biotechnology, 30(5), 259-273. https://doi.org/ 10.1016/j.tibtech.2012.01.004.

Fernandes, Â., Barros, L., Martins, A., Herbert, P., \& Ferreira, I. C. F. R. (2015) Nutritional characterisation of Pleurotus ostreatus (Jacq. ex Fr.) P. Kumm. produced using paper scraps as substrate. Food Chemistry, 169, 396-400. https://doi.org/ 10.1016/j. foodchem.2014.08.027.

Ferreira-Santos, P., Genisheva, Z., Botelho, C., Santos, J., Ramos, C., Teixeira, J. A., \& Rocha, C. M. (2020). Unravelling the Biological Potential of Pinus pinaster Bark Extracts. Antioxidants, 9(4), 334. https://doi.org/10.3390/antiox9040334. 
Firatligil-Durmus, E., \& Evranuz, O. (2010). Response surface methodology for protein extraction optimization of red pepper seed (Capsicum frutescens). LWT - Food Science and Technology, 43(2), 226-231. https://doi.org/10.1016/j.lwt.2009.08.017.

Floegel, A., Kim, D.-O., Chung, S.-J., Koo, S. I., \& Chun, O. K. (2011). Comparison of ABTS/DPPH assays to measure antioxidant capacity in popular antioxidant-rich US foods. Journal of Food Composition and Analysis, 24(7), 1043-1048. https://doi.org/ 10.1016/j.jfca.2011.01.008.

S.O. Gbadamosi S.H. Abiose R.E. Aluko Amino acid profile, protein digestibility, thermal and functional properties of Conophor nut (Tetracarpidium conophorum) defatted flour, protein concentrate and isolates: Functional properties of conophor proteins 4742012731739 10.1111/j.1365-2621.2011.02901.x.

Goiris, K., Muylaert, K., Fraeye, I., Foubert, I., De Brabanter, J., \& De Cooman, L. (2012). Antioxidant potential of microalgae in relation to their phenolic and carotenoid content. Journal of Applied Phycology, 24(6), 1477-1486. https://doi.org/10.1007/ s10811-012-9804-6.

González, A., Cruz, M., Losoya, C., Nobre, C., Loredo, A., Rodríguez, R., Contreras, J., \& Belmares, R. (2020). Edible mushrooms as a novel protein source for functional foods. Food \& Function, 11(9), 7400-7414. https://doi.org/10.1039/D0FO01746A.

Hadidi, M., Khaksar, F. B., Pagan, J., \& Ibarz, A. (2019). Application of UltrasoundUltrafiltration-Assisted alkaline isoelectric precipitation (UUAAIP) technique for producing alfalfa protein isolate for human consumption: Optimization, comparison, physicochemical, and functional properties. Food Research International, 130, 108907. https://doi.org/10.1016/j.foodres.2019.108907.

Ioannou, I., Chekir, L., \& Ghoul, M. (2020). Effect of Heat Treatment and Light Exposure on the Antioxidant Activity of Flavonoids. Processes, 8(9), 1078. https://doi.org/ 10.3390/pr8091078.

Jarpa-Parra, M., Bamdad, F., Wang, Y., Tian, Z., Temelli, F., Han, J., \& Chen, L. (2014) Optimization of lentil protein extraction and the influence of process $\mathrm{pH}$ on protein structure and functionality. LWT - Food Science and Technology, 57(2), 461-469. https://doi.org/10.1016/j.lwt.2014.02.035.

Jayakumar, T., Thomas, P. A., Sheu, J. R., \& Geraldine, P. (2011). In-vitro and in-vivo antioxidant effects of the oyster mushroom Pleurotus ostreatus. Food Research International, 44(4), 851-861. https://doi.org/10.1016/j.foodres.2011.03.015.

Kimatu, B. M., Zhao, L., Biao, Y., Ma, G., Yang, W., Pei, F., \& Hu, Q. (2017). Antioxidant potential of edible mushroom (Agaricus bisporus) protein hydrolysates and their ultrafiltration fractions. Food Chemistry, 230, 58-67. https://doi.org/10.1016/j. foodchem.2017.03.030.

Koutrotsios, G., Mountzouris, K. C., Chatzipavlidis, I., \& Zervakis, G. I. (2014). Bioconversion of lignocellulosic residues by Agrocybe cylindracea and Pleurotus ostreatus mushroom fungi - Assessment of their effect on the final product and spent substrate properties. Food Chemistry, 161, 127-135. https://doi.org/10.1016/j. foodchem.2014.03.121.

Kumar, P., Chatli, M. K., Mehta, N., Singh, P., Malav, O. P., \& Verma, A. K. (2017). Meat analogues: Health promising sustainable meat substitutes. Critical Reviews in Food Science and Nutrition, 57(5), 923-932. https://doi.org/10.1080/ 10408398.2014.939739.

Kurpad, A. V (2013) 'Quality and Sources', in Encyclopedia of Human Nutrition, pp. 123-130. https://doi.org/10.1016/B978-0-12-375083-9.00241-5.

Lavelli, V., Proserpio, C., Gallotti, F., Laureati, M., \& Pagliarini, E. (2018). Circular reuse of bio-resources: The role of Pleurotus spp. in the development of functional foods. Food \& Function, 9(3), 1353-1372. https://doi.org/10.1039/C7FO01747B.

Li-Chan, E. CY. (2015). Bioactive peptides and protein hydrolysates: Research trends and challenges for application as nutraceuticals and functional food ingredients. Current Opinion in Food Science, 1, 28-37. https://doi.org/10.1016/j.cofs.2014.09.005.

Lowry, O. H., Rosebrough, N. J., Farr, A. L., \& Randall, R. J. (1951). Protein measurement with the Folin phenol reagent. Journal of Biological Chemistry, 193, 265-275.

Majesty, D., Ijeoma, E., Winner, K., \& Prince, O. (2019). Nutritional, anti-nutritional and biochemical studies on the oyster mushroom. Pleurotus ostreatus. EC Nutrition, 14(1), 36-59.

Mat, D. J. L., Le Feunteun, S., Michon, C., \& Souchon, I. (2016). In vitro digestion of foods using $\mathrm{pH}$-stat and the INFOGEST protocol: Impact of matrix structure on digestion kinetics of macronutrients, proteins and lipids. Food Research International, 88, 226-233. https://doi.org/10.1016/j.foodres.2015.12.002.
Minekus, M., Alminger, M., Alvito, P., Ballance, S., Bohn, T., Bourlieu, C., Carrière, F., Boutrou, R., Corredig, M., Dupont, D., Dufour, C., Egger, L., Golding, M., Karakaya, S., Kirkhus, B., Le Feunteun, S., Lesmes, U., Macierzanka, A., Mackie, A., Marze, S., McClements, D. J., Ménard, O., Recio, I., Santos, C. N., Singh, R. P., Vegarud, G. E., Wickham, M. S. J., Weitschies, W., \& Brodkorb, A. (2014). A standardised static in vitro digestion method suitable for food - an international consensus. Food \& Function, 5(6), 1113-1124. https://doi.org/10.1039/ C3F060702J.

Nobre, C., Sousa, S. C., Silva, S. P., Pinheiro, A. C., Coelho, E., Vicente, A. A., Gomes, A. M. P., Coimbra, M. A., Teixeira, J. A., \& Rodrigues, L. R. (2018). In vitro digestibility and fermentability of fructo-oligosaccharides produced by Aspergillus ibericus. Journal of Functional Foods, 46, 278-287. https://doi.org/10.1016/j. jff.2018.05.004.

Pillai, C. K. S., Paul, W., \& Sharma, C. P. (2009). Chitin and chitosan polymers: Chemistry, solubility and fiber formation. Progress in Polymer Science, 34(7), 641-678. https://doi.org/10.1016/j.progpolymsci.2009.04.001.

Sá, A. G. A., Moreno, Y. M. F., \& Carciofi, B. A. M. (2020). Plant proteins as high-quality nutritional source for human diet. Trends in Food Science \& Technology, 97, 170-184. https://doi.org/10.1016/j.tifs.2020.01.011.

SATHE, S. K., IYER, V., \& SALUNKHE, D. K. (1982). Functional Properties of the Great Northern Bean (Phaseolus Vulgaris L.) Proteins. Amino Acid Composition, In Vitro Digestibility, and Application to Cookies. J Food Science, 47(1), 8-11. https://doi. org/10.1111/j.1365-2621.1982.tb11014.x.

Simões, L. S., Araújo, J. F., Vicente, A. A., \& Ramos, O. L. (2020). Design of $\beta$-lactoglobulin micro- and nanostructures by controlling gelation through physical variables. Food Hydrocolloids, 100, 105357. https://doi.org/10.1016/j. foodhyd.2019.105357.

Simões, L. S., Martins, J. T., Pinheiro, A. C., Vicente, A. A., \& Ramos, O. L. (2020). $\beta$-lactoglobulin micro- and nanostructures as bioactive compounds vehicle: In vitro studies. Food Research International, 131, 108979. https://doi.org/10.1016/j. foodres.2020.108979.

Tirgar, M., Silcock, P., Carne, A., \& Birch, E. J. (2017). Effect of extraction method on functional properties of flaxseed protein concentrates. Food Chemistry, 215, 417-424. https://doi.org/10.1016/j.foodchem.2016.08.002.

Tolera, K. D., \& Abera, S. (2017). Nutritional quality of Oyster Mushroom (Pleurotus Ostreatus) as affected by osmotic pretreatments and drying methods. Food Science \& Nutr, 5(5), 989-996. https://doi.org/10.1002/fsn3.484.

Ucar, T. M., \& Karadag, A. (2019). The effects of vacuum and freeze-drying on the physicochemical properties and in vitro digestibility of phenolics in oyster mushroom (Pleurotus ostreatus). Food Measure, 13(3), 2298-2309. https://doi.org/ 10.1007/s11694-019-00149-w.

Valverde, M. E., Hernández-Pérez, T., \& Paredes-López, O. (2015). Edible Mushrooms: Improving Human Health and Promoting Quality Life. International Journal of Microbiology, 2015, 1-14. https://doi.org/10.1155/2015/376387.

Vioque, J., Sánchez-Vioque, R., Pedroche, J., Yust, M., \& Millán, F. (2001). Obtención y aplicaciones de concentrados y aislados proteicos. Grasas y Aceites, 52, 127-131.

Windey, K., De Preter, V., \& Verbeke, K. (2012). Relevance of protein fermentation to gut health. Molecular Nutrition \& Food Research, 56(1), 184-196. https://doi.org/ 10.1002/mnfr.201100542.

Wolfe, R. R., Baum, J. I., Starck, C., \& Moughan, P. J. (2018). Factors contributing to the selection of dietary protein food sources. Clinical Nutrition, 37(1), 130-138. https:// doi.org/10.1016/j.clnu.2017.11.017.

Xu, X., Yan, H., Chen, J., \& Zhang, X. (2011). Bioactive proteins from mushrooms. Biotechnology Advances, 29(6), 667-674. https://doi.org/10.1016/j. biotechadv.2011.05.003.

Zhu, F., Du, B., Bian, Z., \& Xu, B. (2015). Beta-glucans from edible and medicinal mushrooms: Characteristics, physicochemical and biological activities. Journal of Food Composition and Analysis, 41, 165-173. https://doi.org/10.1016/j. jfca.2015.01.019.

Zivanovic, S., Buescher, R., \& Kim, S. K. (2003). Mushroom Texture, Cell Wall Composition, Color, and Ultrastructure as Affected by $\mathrm{pH}$ and Temperature. Journal of Food Science, 68(5), 1860-1865. https://doi.org/10.1111/j.1365-2621.2003. tb12343.x. 